\title{
Spatial development as a factor of cities' sustainability
}

\author{
Ivan Makarov ${ }^{1}$, Natalia Morozova ${ }^{1}$, Vladimir Plotnikov ${ }^{2,3,}$, and Tatiana Samoylova ${ }^{1}$ \\ ${ }^{1}$ Financial University (Lipetsk branch), 12 Internacionalnaya str., Lipetsk, Russia, 398050 \\ ${ }^{2}$ Saint-Petersburg State University of Economics, 21 Sadovaya str., St. Petersburg, Russia, 191023 \\ ${ }^{3}$ South West State University, 9450 let Oktiabria str., Kursk, Russia, 305040
}

\begin{abstract}
The article focuses on the spatial conditions of sustainable urban development. They cannot develop without taking into account its inherent tendencies. Using the example of the Russian Federation, the authors performed an analysis of the spatial factor of urban development. The directions of its influence are established; the zoning in the spatial development of the country is highlighted; the laws and tendencies of the transformation of cities under the influence of changes in the economic space were established. The authors substantiated the need to coordinate the development strategies of Russian cities with the measures of the state regional policy. This will allow taking into account the peculiarities of the regions and territories in which the cities are located. It also shows the need for faster development of transport infrastructure in Russia, which increases the coherence of the economic space of the country, stimulates interregional and intercity (inter-settlement) communications. Concerning the zone of the Russian European Core, recommendations were given on prioritizing measures and tools for sustainable urban development. It has been proposed to take into account in the state and municipal policy the main vectors of spatial development (West - East; North - South; Center Periphery).
\end{abstract}

\section{Introduction}

Cities are the drivers of modern socio-economic development. They play an important role as administrative, cultural, industrial, transport centers, etc. Therefore, in public policy, increased attention is paid to the management of cities, urban agglomerations, the formation of their economic structure, the impact on urbanization processes, etc. [1].

We regard the city as a form of spatial organization of the socio-economic system. Therefore, the development of cities and the management of this development should not be considered in isolation from the general regional policy in the country [2]. Urban development should be balanced, consistent with the development of suburban and rural areas, the economic space in general. Imbalances can lead to instability in development and the emergence of socio-economic problems.

\footnotetext{
*Corresponding author: plotnikov_2000@mail.ru
} 
These questions are very relevant for Russia. The Russian Federation is the largest state in the world by area. It has significant regional diversity. It depends not only on the climatic conditions and other natural factors, but also on the "second nature factors" created by man, in particular, on the development of infrastructure [3]. In this regard, the study of the features of spatial development and its impact on cities is of particular importance in this country.

In Russia, there are a significant number of cities and other settlements. According to the Census (2010), there were 1,100 cities in the country, 1,286 urban-type settlements, and 153,125 rural settlements. 163 cities have a population of over 100 thousand inhabitants, 12 Russian cities have a resident population of over 1 million people. The largest of them are Moscow (12.5 million), St. Petersburg (5.3 million), Novosibirsk (1.6 million). Obviously, such a significant number of cities require a differentiated approach to managing them.

\section{Differentiation of regions as a super-system of functioning and development of cities}

The spatial heterogeneity of the socio-economic system is that regions have significantly different characteristics. In this regard, it is required to clarify the concept of "region". An analysis of the literature has shown that the following basic interpretations are used in theoretical studies and in practice: (1) a part of the territory of a country or several countries, distinguished by some common features; (2) an administrative unit; (3) a geographical area with its own name. An important property of a region is not only its difference in some characteristics from other regions, but also the presence of the system integrity of its constituent elements.

In our study performed on the example of the Russian Federation, by region we will mean part of the geographical space of a country that coincides with the boundaries of the administrative-territorial division. As regions of Russia, we will consider the subjects of the Russian Federation (region, territory, republic, autonomous district, autonomous region, city of federal significance). The region is the external environment for the functioning of cities, and in some cases (in Russia it is Moscow, St. Petersburg, Sevastopol) the city itself is considered as a separate region.

The development of the regions of the Russian Federation at the present time is extremely uneven $[4,5,6$, etc.]. There are many reasons for the differences in the levels of socio-economic development of regions. The main ones are:

- Uneven distribution of elements of national wealth, productive forces.

- Differentiation of the population in the regions in terms of number and density, and in terms of education. The contrast is observed between the European and Asian parts of the country. In Russian Europe, whose territory accounts for $25 \%$ of the total area of the country, more than $78 \%$ of the total population lives permanently, and about $22 \%$ of the population lives in Russian Asia, which covers the remaining $75 \%$ of the area. The border between the northern and southern zones of settlement in Russia passes through the cities of St. Petersburg - Kirov - Yekaterinburg - Omsk - Tomsk - Krasnoyarsk Irkutsk - Chita - Khabarovsk. In the main area of settlement, located to the south of this line and occupying about $26 \%$ of the territory, about $95 \%$ of the population is concentrated, and about $5 \%$ live in the north of this line. There are also significant differences between the center and the periphery. About $25 \%$ of the population is concentrated in the Central and North-West economic regions, which cover $4 \%$ of the country's territory.

- A variety of geographical, geopolitical and national-cultural parameters of regions.

- Different legal status of regions; ongoing processes of their consolidation. 
V.N. Leksin and A.N. Shvetsov [7] propose to consider the regional differentiation of modern Russia according to the following criteria (subspaces):

- Natural and climatic subspace. On the territory of the country there are several extensive zones with extreme conditions: arctic, subarctic, permafrost, highland, desert. Most of the country is located in the North. Russia is the country with the coldest climate in the world. More than half of the area is occupied by permafrost. About $75 \%$ of the territory (mainly in the northern and northeastern parts of the country) is unfavorable for human habitation.

- Political subspace. A peculiarity is the presence of territories (zones) with sufficiently stable political preferences of the electorate.

- Legal subspace. It is characterized by unequal legal conditions existing in different regions of the country due to active regional and municipal lawmaking.

- General economic subspace. The main differences are related to the models and degree of state regulation of the economy, the level of development of the real sector of the economy, shares of the "shadow" economy, business structure, etc.

- Natural resource subspace. It is characterized by an uneven territorial distribution of the vast majority of economically significant types of natural resources. For example, about $60 \%$ of the export and raw material potential of the Russian Federation is located in Siberia. Western Siberia currently concentrates $90 \%$ of the exported oil, almost $100 \%$ of natural gas, and about $60 \%$ of the coal is mined here. A significant part of the mining and metallurgical industries is concentrated in Eastern Siberia, providing $85 \%$ of exports of aluminum, $70 \%$ of copper and $50 \%$ of nickel.

- Economic and object subspace. Characterized by unequal distribution of productive forces in the country. This subspace took shape during the USSR period due to the implementation of centralized planning documents: location schemes for enterprises and infrastructure facilities.

- Transport and infrastructure subspace. There is a significant difference in the level of security of the territories with transport and other infrastructure, which has a pronounced latitudinal and meridional character.

- Social subspace. The Russian Federation is characterized by the asymmetry of the territories in terms of the level and quality of life.

- Confessional subspace. The country has all the world religions in combination with a significant number of local beliefs and sects.

- National-ethnic subspace. The population of modern Russia is almost $80 \%$ ethnic Russian, while more than 100 different ethnic groups reside in the country.

The heterogeneity of the economic, climatic, natural resource and other subspaces of the Russian Federation contribute to the complication of urban development processes; creates obstacles for development or unreasonable advantages. These factors should be taken into account in urban development strategies.

It should also point to globalization. This is a new factor influencing the development of cities and regions of their presence. Cities are drivers of globalization processes. Large cities are the most globalized forms of spatial organization of national socio-economic systems. Through the development of cities is the impact of globalization and the regions of their presence. The presence of a large city in the region in the context of globalization is becoming a factor, on the one hand, accelerating its pace of development, on the other hand - increasing the volatility of growth rates, reducing the sustainability of development. 


\section{Regulation of spatial development to improve urban sustainability}

Increasing the homogeneity of the economic space, reducing its differentiation integrates the regions, contributes to sustainable urban development. In this regard, state policy measures on spatial development should be focused on the following areas:

- Stimulation of the formation of interregional and intercity trade and economic relations at the level of subjects of the federation and municipalities.

- Assistance to enterprises in the formation of territorial economic clusters and the development of other forms of industrial cooperation [8]; implementation of import substitution policy.

- Expansion of humanitarian contacts between regions and cities, cultural exchange.

- Construction (including in the form of a public-private partnership) trans-regional production and transport infrastructure.

- The implementation of special measures to reduce the unevenness of spatial development at the expense of the federal budget. At the same time, special support is needed for cities that can act as growth poles at the regional and national levels.

Given the enormous distances inherent in Russia, the development of transport and telecommunications infrastructure is of particular importance for regulating its spatial development. This development, initiated by the authorities, further promotes the launch of market mechanisms of self-development. On the roads of major roads, entrepreneurship is becoming more active, new settlements are being formed; the development of cities is accelerating.

For example, the construction of the first high-speed railway Moscow - Vladimir Nizhny Novgorod - Kazan in Russia will lead to the creation and modernization of 16 new stations. 6 stations will be located in large cities and 10 - in small ones. All stations have passed city planning expertise and are ready for implementation. They will become growth poles for the surrounding areas. Planned construction of new residential areas, industrial parks, transportation hubs. During the project implementation and after its completion, 370 thousand jobs will be created. The multiplier effect for the economy on this project will be 3.7 [9].

According to D.S. L'vov [10], the list of priority transport projects that will increase the coherence of the country's territory and give impetus to economic growth should include:

- Modernization of the Trans-Siberian Railway and completion of the construction of the Western Europe - Far East highway.

- Construction of the North-Siberian Railway, which should be the second transport corridor in the East-West direction through Siberia, using the Baikal-Amur Railway as its eastern section.

- Development of the Northern Sea Route;

- In the future, it is possible to build a transcontinental automobile and/or railway Russia North America with a tunnel through the Bering Strait.

The implementation of the spatial development policy should take into account the zoning of the country's territory, which determines, among other things, the conditions for the functioning of cities in various zones. We distinguish the following zones in Russia: European North, European Core, the Urals, the North Caucasus, Western Siberia, Eastern Siberia, and the Far East. The main part of Russian cities is located on the territory of the European Core, which includes the North-Western, Central, Central Chernozem, VolgaVyatka and Volga economic regions.

The vectors for the development of cities in the North-West economic region are: (1) the development of transport and warehouse complexes, the creation and development of logistics centers, the expansion of the infrastructure of all types of transport; (2) the 
development of knowledge-intensive industries (instrument making, shipbuilding, pharmaceuticals, etc.) and scientific and educational potential; (3) development of large cities (primarily St. Petersburg) as national and supranational service centers (financial, informational, consulting, tourist and other services).

The central economic region is the most powerful in Russia in terms of economic potential. The administrative, economic and political center of the European part of Russia is Moscow or the Moscow agglomeration, which also includes a part of the Moscow region with satellite towns. Moscow is one of the largest cities in the world, a transportation hub, a world-class industrial, cultural, and scientific center. There are plans to form the International Financial Center in Moscow. The Bryansk, Vladimir, Ivanovo, Kaluga, Kostroma, Oryol, Ryazan, Smolensk, Tver, Tula and Yaroslavl Regions also belong to the Central Economic Region. These are old industrial regions. In their cities, the advanced development of the manufacturing industry (transport and heavy mechanical engineering, instrument-making, light industry, chemical industry, etc.) is required.

The Central Chernozem economic region consists of Belgorod, Voronezh, Kursk, Lipetsk and Tambov regions. The drivers of the development of their cities are ferrous metallurgy, mechanical engineering and metalworking, the building materials industry, and the food industry.

The Volgo-Vyatsky economic region is characterized by a high level of uneven economic development in its constituent regions - most of the economic potential falls on the Nizhny Novgorod region with the metropolis of Nizhny Novgorod, and a significant part of the remaining share is on the Kirov region. Republic of Mordovia, Mari El, Chuvashia in terms of economic development significantly lag behind other regions of the European part of Russia.

The Volga economic region consists of Astrakhan, Volgograd, Penza, Samara and Saratov regions, the republics of Kalmykia and Tatarstan. One of the main industries ensuring the development of cities in this area is the oil refining industry, which produces a significant part of fuel oil, synthetic resins and plastics in the country.

We distinguish four vectors of spatial development that affect the functioning of Russian cities:

- West - East. This vector is due to the historical dynamics of the economic development of the territory of Russia. The west of the country is more developed, and the east is less. Cities in the western part of the country have a higher level of development, but they face a large number of restrictions. Cities in the eastern part of the country have prospects for development, but they need significant resources.

- North - South. The main cause of this vector is the presence of latitudinal zonality. Despite the fact that a significant part of the territory of Russia falls into the zone of the North, the bulk of the population is concentrated in the middle zone, which has about $30 \%$ of the area and about $70-80 \%$ of GDP and the population of the Russian Federation [11]. Especially we highlight the Arctic zone of the Russian Federation. There is a very low level of development of the territory, a small number of cities. The development of the territory takes place on the focal principle. A few cities in these conditions automatically become growth poles. But their functioning requires very significant resources.

- Center - Peripherals. As we showed above, the economic space of Russia is differentiated. There are regions (cities) leaders, growth poles, as well as regions (cities) with the worst development indicators. At the same time, in general, the standard of living in cities is higher than in rural areas, which leads to active migration of the population to cities, especially the regional centers [12]. There is a problem of equalizing the living conditions of the population in cities and other settlements, especially rural ones. 


\section{Conclusion}

The spatial development of Russia is uneven. Over time, differentiation increases. This has a direct impact on the development and functioning of cities. In this regard, their sustainable development strategies should be consistent with spatial development policies. Also, when developing strategies for cities, the specifics of their territorial location should be taken into account. This specificity has a significant impact on the priorities of sustainable urban development in Russia.

\section{Acknowledgements}

The paper is an output of the science project of the government task of Ministry of education and science of the Russian Federation \#26.3546.2017/PCH "Development fundamentals of analysis and prediction of structural and dynamic parameters of the regional economy are based on the integration of the Russian and world experience of management of territorial development and modern scientific doctrines".

\section{References}

1. D. Rauhut, N. Hatti, Social Science Spectrum 3(1), 1-15 (2017)

2. J.R. Gil-Garcia, T.A. Pardo, T. Name, Information Polity 20, 61-87 (2015)

3. I. Makarov, V. Plotnikov, MATEC Web of Conferences 170, 05012 (2018) doi: 10.1051/matecconf/201817005012

4. Y.L. Makarova, A.V. Polyanin, Izvestiya South-West State University 2, 36-48 (2014)

5. Y. Vertakova, Y. Polozhentseva, M. Klevtsova, I. Ershova, Proceedings of the 30th International Business Information Management Association Conference, IBIMA 2017

- Vision 2020: Sustainable Economic development, Innovation Management, and Global Growth 1, 1834-1843 (2017)

6. V.M. Razumovsky, Izvestia of St. Petersburg State University of Economics 1-1(103), 107-114 (2017)

7. V.N. Leksin, A.N. Shvetsov, Russian Economic Journal 11-12, 36-44 (1999)

8. Y. Vertakova, V. Plotnikov, Economic Annals-XXI 156(1-2), 37-40 (2016) doi: 10.21003/ea.V156-0008

9. D.S. L'vov, The path to the 21st century: Strategic problems and prospects for the Russian economy (Economics Publishing, Moscow, 1999)

10. V. Plotnikov, M. Kutepova, O. Sushko, Advances in Economics, Business and Management Research 39, 706-709 (2018)

11. B. Cohen, World Development 32(1), 23-51 (2004) 